The Ape in the Tree: An Intellectual and Natural History of Proconsul, by Alan Walker and Pat Shipman (288 pages, April 2005), tells the fascinating story of the discovery and history of the Miocene ape genus Proconsul, a skull of which was rst found by anthropologist Mary Leakey on Rusinga Island in Lake Victoria, Kenya, in 1948. Now thought to be the last common ancestor of modern apes and humans, this tailless, fruit-eating, monkey-sized primate lived in Africa between 21 and 14 million years ago. Anthropologist Walker also describes his expeditions to the island in the 1980s to nd more Proconsul fossils. The authors enthusiasm for the topic is contagious, and their ability to transform often-dry paleontological analysis into a potential screenplay for CSI: Kenya is admirable. \$26.95. Belknap Press of Harvard University. ISBN 0-674-01675-0.

Born Again-in Exile: Poems, by Mirela Roznoveanu (134 pages, May 2004), offers an intriguing selection of poetry by this Romanian literary critic and writer who has called New York City her home since 1991. The majority are translations of Romanian-language originals, lled with classical allusions ( Exposed like an infant on the Tarpeian Rock ), natural imagery (And willows bored with too much weeping ), revelations of self-discovery ( The ower of life has turned today toward me ), and fear and melancholy ( Like a bag of camphor grains on a string/ we wear dread around our neck ). Perhaps her most vivid verses are in the ten poems about New York that capture the excitement and anxieties felt by the newly arrived ( Park Avenue is the new Via Appia/with the delirium tremens of its opulent dinners ). Roznoveanu now works as a researcher and assistant professor in New York University s

George M. Eberhart is senior editor of American Libraries, e-mail: geberhart@ala.org
Law School Library. Her 2004 book of short stories, The Life Manager and Other Stories, is also worth a look. \$13.95. iUniverse. ISBN 0-595-31831-2.

Pages from the Past: History and Memory in American Magazines, by Carolyn Kitch (256 pages, September 2005), justi es retaining extended runs of popular periodicals in the library as cultural narratives of American life. Kitch offers examples from some 60 magazines published in the past 25 years to demonstrate that what most people know about the American past is encoded in stories, which today are told primarily through the media. She focuses on the self-appointed status of news magazines as national leaders, the events of September 11 as recognizable American mythology, common themes in celebrity deaths, visual imagery in African-American identity, the role of the media in generational nostalgia, the presentation of the past as a simpler and better time and place, and the role of consumer magazines in characterizing thematic history as vital to American culture. Shelve this one in the periodicals collection. \$49.95. University of North Carolina. ISBN 0-8078-2967-6.

Restoring Free Speech and Liberty on Campus, by Donald Alexander Downs (295 pages, March 2005), reviews four case studies involving academic policies developed in the late 1980s and 1990s to foster civility and tolerance on campus. Downs offers an objective perspective on Columbia University s 2000 sexual misconduct policy; the status of free speech in the public forum at Berkeley and in Boalt Law School from 1997 to 1998; the 1993 water buffalo case that resulted in the removal of the student speech code at the University of Pennsylvania; and the institutional consequences of the 1999 abolition of the faculty speech code at the University of Wisconsin-Madison. He concludes 
that academic enforcement of codes that favor special categories of race or gender, however well-intended, often harms the would-be bene ciaries because they assume that such students are incapable of handling the rigors of open debate and due process. \$28.99. Cambridge University. ISBN 0-521-83987-4.

\section{Saving Higher Education in the Age of Mon-} ey, by James Engell and Anthony Dangereld (277 pages, May 2005), examines the disinvestment in the humanities, the decline of reading assignments, shrinking academic library budgets, and the marginalization of the liberal arts and sciences as some of the many symptoms of an overwhelming public perception of higher education as an investment that must be repaid. An academic declaration of principles, this book shows that economic advancement is only one of several interdependent bene ts conferred by a college degree. $\$ 27.95$. University of Virginia. ISBN 0-8139-2331-X.

Veritas: Harvard College and the American Experience, by Andrew Schlesinger (304 pages, June 2005), explores the social con icts in Harvard s history as a series of

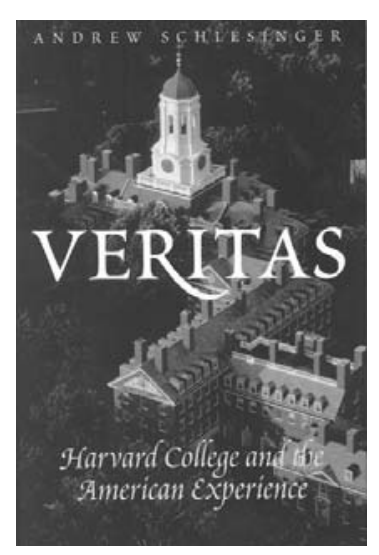

clashes between the universitys motto of veritas (truth) and impediments to truth (sectarianism, racism, aristocracy) from Puritan times to the 21st century. Schlesinger portrays Harvard student life against the backdrop of such issues as the American Revolution, slavery, fascism, diversity, the Vietnam War, multiculturalism, and the current administration of President Lawrence Summers. \$27.50. Ivan R. Dee. ISBN 1-56663-636-1.

The War Aims and Strategies of Adolf Hitler, by Oscar Pinkus (537 pages, June
2005), spells out in great detail the dynamic of Hitler s objectives in starting World War II and persisting in its execution long after his chances for victory had eroded. Pinkus argues convincingly that his primary aim was the conquest of Eastern Europe and Russia up to the Urals, a geoethnic cataclysm in which the Eastern peoples were to be halfexterminated and half-converted into serfs to toil in a vast Teutonic empire ruled by settled Nazi barons. War with England and America was an annoying sideshow. However, by 1942, facing ultimate failure, Hitler devoted his efforts to the obliteration of enemy and ally alike, including the destruction of Germany itself. In the course of researching this book over the past 50 years, Pinkus made use of many sources written in Polish, German, Russian, Italian, Hebrew, and Yiddish that have never been translated into English. \$45.00. McFarland. ISBN 0-78642054-5.

The F hrers obsessive European blitzkrieg has long captured the imagination of writers of alternative historical scenarios in which the Wehrmacht wins the war, Hitler survives it as a fugitive, or he either never existed or died much earlier. The World Hitler Never Made, by Gavriel D. Rosenfeld (524 pages, June 2005), reviews this literature in depth, from comics and novels to Twilight Zone episodes, Saturday Night Live skits, and $\operatorname{lm}$ treatments. $\$ 30.00$. Cambridge University. ISBN 0-521-84706-0.

William Anthony, Fine Binder, edited by Lawrence Yerkes (70 pages, 2005), commemorates the 21st anniversary of the University of Iowa s conservation lab by showcasing more than 100 color photographs of the work of master book binder Bill Anthony (d. 1989). This exhibition catalog includes illustrations of Anthonys design bindings (those that re ect the content of the book), edition bindings, conservation work, and historical models. A glossary de nes such terms as doublure, nipping press, and spatter paper. \$39.95. University of Iowa Libraries. ISBN 0-87414-150-8. $n$ 